\title{
In Ecclesia Nostra: The Collatiehuis in Gouda and Its Lieux de Savoir
}

PIETER H. BOONSTRA (D)

बसम

Open Library of Humanities

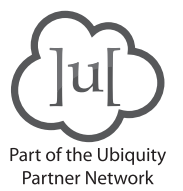

CORRESPONDING AUTHOR:

\section{Pieter H. Boonstra}

University of Groningen, NL P.H.Boonstra@rug.nl

KEYWORDS:

spatiality; communication of knowledge; collatio; lieux de savoir

TO CITE THIS ARTICLE: Boonstra, Pieter H. "In Ecclesia Nostra: The Collatiehuis in Gouda and Its Lieux de Savoir." Le foucaldien 7, no. 1 (2021): 5, 1-13. DOI: https:// doi.org/10.16995/lefou.93 


\section{INTRODUCTION}

In the year 1445, a small community of Brothers of the Common Life took up residence in the Dutch city of Gouda, in a house located in the Spieringstraat. This community represented an urban branch of the Devotio moderna or Modern Devotion, the most renowned religious movement in the late medieval Low Countries. The Brothers took no vows but pledged to live a humble and communal life in service of God. With the house in Gouda came a small library; among the books were theological texts, a Bible in two parts, and "a Dutch book of collations." This 'book of collations' was a collection of devout religious texts-collations-meant to be read to an audience of students and laypeople, during a meeting (the collatio) taking place under the care of the Brothers, usually on Sundays and feast days in the afternoon. The collationes were part of the outreach from the Brothers, as they invited laypeople to visit their houses and participate in the reading of a religious text, followed by an informal, personal conversation. To prevent accusations of preaching in secret, these meetings were primarily framed as the reading of a devout text in the vernacular followed by spiritual conversation. Text and practice are thus intricately linked; indeed, in contemporary sources both are referred to with the same word collatio or (Middle) Dutch collatie/collacie. For clarity, this article uses 'collatio' to refer to the practice, whereas 'collation' refers to the written text to be read. ${ }^{2}$ With the help of the textual collations, collationes allowed the Brothers to communicate their religious knowledge and devotional attitudes to a lay audience. In Gouda, however, such meetings were already taking place before the Brothers had established a community and were strongly tied to a specific place-the 'house of the collatio', or Collatiehuis.

The name 'Collatiehuis' reveals a strong connection between the location and the meetings that took place there, a prime example of what Christian Jacob has termed lieux de savoir. ${ }^{3}$ The term lieux de savoir strongly lends itself to a spatial approach: the space in which knowledge was constructed, circulated, and communicated, and the locations where such processes took place. In his Qu'est-ce qu'un lieu de savoir, Jacob emphasises the importance of location and physical context for the translation of knowledge, most tellingly in his chapter on "The spatial turn". For the collatio this approach is indeed highly informative, as the practice was explicitly tied to a historical place and time. Since the collatio was aimed at the communication of religious knowledge, the concept of lieux de savoir encourages an exploration of the exact place where the collatio circulated its message, and how it might have been influenced by these physical spaces. This entails not only the room within the Collatiehuis where the collatio took place but also the location of the house within the city of Gouda: visitors of the collatio were not static entities but could move around in search of other devotional activities as well. For the urban laypeople, the Collatiehuis constituted but one lieu de savoir amidst a multitude of others: the city presented a network of interconnected spaces in which (religious) knowledge was communicated. ${ }^{4} \mathrm{~A}$ focus on the spaces in which laypeople interacted with religious professionals and were engaged with the transmission of knowledge opens up new insights into the dynamic nature of late medieval urban devotion.

The concept of lieux de savoir can also be further developed by focusing on the construction and circulation of knowledge, as different forms of communication were involved in the collatio. The private conversations between the Brothers of the Common Life and visiting laypeople were for the most part oral communication, though the religious texts through which the Brothers constructed their spirituality would always form part of the context being present 1 The Brothers drew up several inventories of the books found in the house: Gouda, Streekarchief Midden-
Holland (hereafter: SAMH), Archieven van de kloosters te Gouda, 0091.16 (Lijsten van huisraad en boeken, met
het Collatiehuis van de Heilige-Geestmeesters ontvangen, en een opsomming van huisrenten, toebehorende
aan het Collatiehuis, ca. 1438-1447/1456, 1438-1456). Jan Willem Klein came to a total of 11 complete
copies of this list and another partial copy: Jan Willem Klein, "De Goudse boekcultuur tot 1600: Het begin en de
Collatiebroeders," Tidinge van die Goude 38 (2020), 92-93.

2 See also Pieter H. Boonstra, "Causa Spiritualis Instructionis. The Modern Devout Collatio as a Community of Learning," Ons Geestelijk Erf 88 (2017): 35-57; compare Lydeke van Beek, Leken trekken tot Gods woord. Dirc van Herxen (1381-1457) en zijn Eerste Collatieboek (Hilversum: Verloren, 2009), 63-64.

3 Theorized in Christian Jacob, Qu'est-ce qu'un lieu de savoir?, Encyclopédie numérique 2 (Marseille: OpenEdition Press, 2014), http://books.openedition.org/oep/423.

4 See for instance John Van Engen, "Multiple Options: The World of the Fifteenth-Century Church," Church History 77 (2008): 257-84. 
in the background. ${ }^{5}$ Yet the collective part of the collatio made use of both textual and oral communication: in reading a collation, the collatio involved the translation from written text to spoken word. In this situation, the book of collation can be seen as a lieu de savoir as it plays a pivotal role in the construction of knowledge and its subsequent transmission. Thus, within the physical lieu de savoir of the Collatiehuis, the book of collations functioned on the border between the physical and the abstract: a material object with ties to the religious praxis of the Brothers of the Common Life.

To explore these three levels of lieux de savoir, the present article will open with a short history of the Collatiehuis as an institution, stressing the importance of the collationes to the building - even before the Brothers of the Common Life established themselves in Gouda, and even when the house was uninhabited. Afterwards, the interior of the Collatiehuis will be explored insofar as is still possible, with emphasis on the rooms used for the collatio. Thirdly, the place of the Collatiehuis within Gouda will be considered, as the building stood in close proximity to the parochial church and other religious institutions. The Brothers also maintained relations with other groups in the city: the Collatiehuis was tied to Gouda in more ways than just geographically. The article will close with a consideration of the books of collations as lieux de savoir, as these were the instruments with which laypeople were engaged with the devotional knowledge of the Brothers of the Common Life.

\section{HISTORY OF THE COLLATIEHUIS}

In the course of the fifteenth century, three different buildings were known as the Collatiehuis. The first Collatiehuis had been the home of Dirk Florisz., priest in Gouda. ${ }^{6}$ He gifted it - together with a small library and a yearly stipend-to the Chapter of Sion in 1425 , on the condition that two or three Regular Canons from the local monastery of Stein would live there and provide a 'devotional speech' to the common people, every Sunday after the vespers. ${ }^{7}$ This would be the main function of the building: if the Regular Canons were unable to provide collationes then they were to relinquish the house and all property belonging to it to the Holy Ghost masters (Dutch: Heilige Geestmeesters) in Gouda, who in turn were to take care of the collationes. The Holy Ghost masters thus maintained supervision over the Collatiehuis as they did for multiple religious institutions in the city, and if its original function of providing collationes was not respected, ownership of the building defaulted to them. ${ }^{8}$

The first Collatiehuis was destroyed by a great fire in 1438, and from its ashes the Regular Canons raised the second Collatiehuis. They continued the collationes for a time, but dropped the house and its corresponding responsibilities in 1443, after which the Holy Ghost masters took possession of the house. They did not provide collationes themselves, but invited other priests to do so, for a period of two years. ${ }^{9}$ This arrangement was not satisfactory, however, and in 1445 they convinced Hendrik Herp - who by then had already made a name for himself as an accomplished preacher, and who would later leave the Brothers for the Franciscan order instead - to make the Collatiehuis a 'daughter-house' of the Brothers of the Common Life in Delft. ${ }^{10}$ As the individual houses of the Brothers in different cities operated largely autonomous

5 Indeed, the Brothers of the Common Life, or the Modern Devotion more generally, are a clear example of a textual community where the text need not always be physically present to be influential. Such might even be the core of a textual community: see Brian Stock, The Implications of Literacy. Written Language and Models of Interpretation in the Eleventh and Twelfth Centuries (Princeton: Princeton University Press, 1983), 90-91; Nikolaus Staubach, "Die Devotio moderna als Textgemeinschaft," in Schnittpunkte. Deutsch-Niederländische Literaturbeziehungen im späten Mittelalter, ed. Angelika Lehmann-Benz, Ulrike Zellmann, and Urban Küsters (Münster: Waxmann, 2003), 19-40

6 For a concise history of the house and the community living there, see Anton G. Weiler, Volgens de norm van de vroege kerk. De geschiedenis van de huizen van de broeders van het Gemene leven in Nederland, Middeleeuwse Studies, XIII (Nijmegen: Centrum voor Middeleeuwse Studies Katholieke Universiteit Nijmegen, 1997), 138-42.

7 Johannes H. Carlier, "Het Fraterhuis of Collatiehuis op de Jeruzalemstraat," Bijdragen Oudheidkundige Kring Die Goude (Gouda) 5 (1947): 52-53.

8 On the Holy Ghost masters in Gouda, see Koen Goudriaan, Martha Hulshof, and Ad L. Tervoort, with Bart Ibelings, "Rijk liefdewerk in een arme stad," in Duizend jaar Gouda. Een stadsgeschiedenis, by Paul H.A.M. Abels, Bijdragen/Historische Vereniging Die Goude 30 (Hilversum: Verloren, 2002), 144-45.

$9 \quad$ Weiler, Volgens de norm van de vroege kerk, 139.

10 Anna Dlabačová, Literatuur en observantie. De Spieghel der volcomenheit van Hendrik Herp en de dynamiek van laatmiddeleeuwse tekstverspreiding, Middeleeuwse Studies en Bronnen, CXLIX (Hilversum: Verloren, 2014), $30-31$. 
from each other, Herp was allowed to accept the request despite objections from the community in Delft and from the Colloquium of Zwolle, the organisational network in which the individual houses regularly met and discussed common interests. Herp initially appointed Bernard Lochem as rector of the Collatiehuis, a decision which the Colloquium of Zwolle overruled the next year, forcing Herp himself to lead the house in Gouda. ${ }^{11}$ The Collatiehuis was officially transferred to the Brothers of the Common Life in 1447: three Brothers from the community in Delft, Herp among them, moved to Gouda.

Herp left the Collatiehuis in 1450, joining the Observant Franciscans instead. Leadership passed to Johan Pupper van Goch but the community struggled, both financially and physically: when Johan van Goch was forced to leave Gouda in 1454 because his collationes got him into trouble with the local clergy, there were no Brothers of the Common Life left and ownership of the Collatiehuis passed once more to the Holy Ghost masters. ${ }^{12}$ After Johan van Goch had left the house, it stood empty for two months yet it was still in use: the guild of chamois leatherworkers (Dutch: zeembewerkers) installed a watchman for the building, and the rector of the local Magdalena convent took care of the collationes until Johannes Voppens was installed as the new rector. ${ }^{13}$ In 1456 the Collatiehuis officially joined the Colloquium of Zwolle, leading to a period of relative prosperity, though the community never truly flourished.

Between 1460 and 1485 the house was intensively renovated and expanded, to the extent that the Collatiehuis was effectively rebuild as a new building. ${ }^{14}$ During this time a small church or chapel was raised and consecrated as well, though it has not survived to this day: in 1943 it was torn down, along with the rest of the buildings. The Jeruzalemkapel, however, acquired by the Brothers as a gift from Gysbert Raet, priest in Gouda, still stands. ${ }^{15}$ The community of Brothers of the Common Life took care of the Collatiehuis up to the late $16^{\text {th }}$ century, albeit with difficulty. In 1573 the few remaining Brothers returned the house to the Holy Ghost masters, who used it as an orphanage. ${ }^{16}$

\section{INSIDE THE COLLATIEHUIS}

From the history of the Collatiehuis, it is clear that it offered a place for collationes since Dirk Florisz. designated it as such in 1425. Thus, the building itself was a lieu de savoir: it provided a clear space in which religious knowledge could be shaped and communicated between religious professionals and participating laypeople. In its entirety, the house functioned as a lieu de savoir on two levels of differing scope. On a lower level, the Collatiehuis was composed of several smaller lieux de savoir: the rooms in which the collatio and the ensuing conversation took place, shaping the interaction between the Brothers and their lay visitors and facilitating different modes of communication, are spaces of knowledge in their own right. From this angle, the Collatiehuis is more than the sum of its parts. Laypeople would know to visit the Collatiehuis to participate in the communication of religious knowledge; once they had entered the building, the Brothers would guide them to different places which facilitated different forms of communication.

Determining the exact floor plan of the Collatiehuis is by necessity something of an educated guess. Certainly the building must have had at the least one room large enough to contain a small gathering, or it could not have functioned as a designated place for collationes. It is possible-especially after the rebuilding of the Collatiehuis in 1438-that it had a separate room where the collationes could be held. In the vita of Jacobus de Voecht, chronicler of the Gregoriushuis in Zwolle, a [camera] collationum is mentioned, which is supposedly the room in

11 Weiler, Volgens de norm van de vroege kerk, 139; Dlabačová, Literatuur en observantie, 32-34.

12 On the conflict between Johan van Goch and the local clergy, see Anton G. Weiler, "The Dutch Brethren of the Common Life, Critical Theology, Northern Humanism and Reformation," in Northern Humanism in European Context, 1469-1625. From the 'Adwert Academy' to Ubbo Emmius, ed. Fokke Akkerman, Arjo J. Vanderjagt, and Adrie H. van der Laan (Leiden: Brill, 1999), 317-22.

13 Carlier, "Het Fraterhuis of Collatiehuis," 56.

14 See in particular Johannes Taal, De Goudse kloosters in de middeleeuwen (Hilversum: Paul Brand, 1960), 60-63.

15 Anton G. Weiler, Monasticon fratrum vitae communis, TI. III: Niederlande (Brussel: Archives et bibliothèques de Belgique, 2004), 220.

16 Weiler, Volgens de norm van de vroege kerk, 141-42. 
which the collatio would take place. In this case, the room was used as a makeshift sickroom when De Voecht and a fellow brother, Hubertus Gueden, had fallen ill. Two beds had been placed in the room; apart from these, it also contained a small table and a hearth or fireplace. ${ }^{17}$ Whether a similar arrangement was made for the Collatiehuis is unclear. Regardless, any design for a designated place for the collatio would have been an independent idea of the Regular Canons who were at the time responsible for the Collatiehuis and had rebuilt the house after the fire. Only from 1445 onward did the Brothers of the Common Life have ties to the Colloquium of Zwolle. The community in Deventer might not have had a dedicated room for the collatio after the move to a new house in 1391, though the very first Brothers did: Florens Radewijns had reserved one of the rooms in his house for the collationes the Brothers practiced together. ${ }^{18}$ It seems there was no specific room set apart for providing collationes to visiting laypeople however, as both Florens as well as lay Brother Johannes Kessel gave collationes to students in the entry hall of the house. ${ }^{19}$

Later on, it is possible to identify several locations in particular where (parts of) the collatio took place. The second house, built after the fire of 1438 , had a dining room or refter in the back where the Brothers practiced the collatio among themselves. ${ }^{20}$ In the front, there was a chapel which was used for the public collationes; indeed, the consuetudines explicitly state that they should take place in ecclesia nostra. ${ }^{21}$ The year of construction for this initial chapel is unknown, but around 1462 a new and larger chapel (perhaps up to 23.40 by 10.70 meters) was built under rector Hendrik van Arnhem. ${ }^{22}$ The chapel with its five altars, cemetery, and another portable altar was initially consecrated on 15 August 1462, and consecrated once more around 1474-1476. ${ }^{23}$ In several Modern Devout communities, the chapel was the designated place for collationes, either public or private. Female communities (Sisters of the Common Life or affiliated communities) in particular made use of their chapel. In some cases, they were even allowed to open the doors of their chapel during the collatio so that interested laypeople could visit them as well. This was, for instance, the case in Leiden, where the sisters of St. Agatha had obtained permission in 1459 to have daily collationes in their chapel, during which they could open their doors when no services were being held in the parish church. ${ }^{24}$ This stipulation was a common element in arrangements between the Brothers of the Common Life and local parishes as well. In Zwolle, the Brothers were granted special permission from Hendrik van Compostella, the city pastor, for the collatio "at those times when there are no divine services in the church, or sermons." 25 The consuetudines of the Collatiehuis also make it clear the collatio is not to compete with the regular services in the church: the Brothers have to wait until the vespers are finished. ${ }^{26}$ It is uncertain how many people on average attended a collatio, but the meetings still potentially pulled visitors away from the parish church-necessitating agreements between the Brothers and the local parish.

17 Michael Schoengen, ed., Jacobus Traiecti alias De Voecht: Narratio de inchoatiane domus clericorum in Zwollis. Met akten en bescheiden betreffende dit fraterhuis (Amsterdam: Johannes Müller, 1908), 162: "Quamdiu ergo potuimus, sedebamus ad unam mensulam juxta ignem in camera, scilicet collationum, ubi et dormiebamus."

18 John Van Engen, Sisters and Brothers of the Common Life. The Devotio Moderna and the World of the Later Middle Ages (Philadelphia: University of Pennsylvania Press, 2008), 285.

19 Bonaventura Kruitwagen, "Het "Speculum Exemplorum"," Bijdragen voor de Geschiedenis van het Bisdom van Haarlem 29 (1905): 388-90; Van Engen, Sisters and Brothers, 285.

20 On the building history of the Collatiehuis, also see Koen Goudriaan, "De verdwenen kloosters," in Gouda, ed. Wim Denslagen, De Nederlandse monumenten van geschiedenis en kunst (Zwolle: Waanders, 2001), 189-95.

21 Albert Hyma, The Christian Renaissance. A History of the 'Devotio Moderna' (Grand Rapids, MI: The Reformed Press, 1924), 448: "[...] pro communi populo facere in ecclesia nostra." Hyma considered this set of consuetudines to be those of Deventer, but they have since been attributed to Gouda: Constant A.M. Lem, "De consuetudines van het Collatiehuis in Gouda," Ons Geestelijk Erf 65 (1991): 125-43; Theo Klausmann, Consuetudo consuetudines vincitur. Die Hausordnungen der Brüder vom gemeinsamen Leben im Bildungs- und Sozialisationsprogramm der Devotio moderna, Tradition - Reform - Innovation. Studien zur Modernität des Mittelalters 4 (Frankfurt am Main: Peter Lang, 2003), 239-45.

22 Taal, De Goudse kloosters in de middeleeuwen, 58-62; Weiler, Volgens de norm van de vroege kerk, 147.

23 Taal, De Goudse kloosters in de middeleeuwen, 59-61; Weiler, Volgens de norm van de vroege kerk, 147.

24 Madelon van Luijk, Bruiden van Christus. De tweede religieuze vrouwenbeweging in Leiden en Zwolle,

1380-1580. (Zutphen: Walburg Pers, 2004), 96.

25 Van Beek, Leken trekken tot Gods woord, 61; Schoengen, Narratio, 427.: "[...] temporibus quibus non fiunt divina officia in ecclesia vel sermones [...]." 
To facilitate the individual part of the collatio-where a Brother would take a visitor to his room for some personal admonitions - five or six small cells were constructed in 1446 during Hendrik Herp's time as rector. These were located under the roof of the house, in the attic. Possibly the Brothers also used their rooms to copy books, in the absence of a scriptorium. ${ }^{27}$ They would at the least keep a religious text in their room for their personal meditation, which they might use to illustrate a point made during the conversation. Participants in the collatio were thus physically transported to a different, more private level of the community of Brothers of the Common Life. Whether it was only men who visited the Brothers in private or if women were allowed to as well is unclear; the chapel in particular was accessible to women to attend the communal reading, but as to the individual admonitions the consuetudines only state that the conversation should last no more than half an hour. Regardless of their gender, in venturing deeper inside the building visitors were also being guided deeper into the Modern Devout spirituality. The more intimate setting-a smaller space, and a one-on-one conversationaided the communication of religious knowledge; indeed, such was the intent of the Brothers from the start. The Gouda consuetudines explicitly state that they wished to touch the visitors' hearts and desires with moving and humble words. ${ }^{28}$ Those of Zwolle even explain the need to speak to some of the participants privately: some personal encouragement is more effective and can be adjusted to the wants and needs of the individual visitor. ${ }^{29}$ The communal reading with all participants in a single room would speak to the mind, yet the heart was touched when separated from the group, in the privacy of a one-on-one conversation. A shift in space thus accompanied a shift in tone and a different mode of communicating devotional knowledge: within the same building, the collatio made use of interconnected yet separate lieux de savoir to amplify its message.

As to the physical (dis)comfort of the collationes in the Collatiehuis, only informed conjecture is possible. During the communal part of the collatio the listeners would presumably be seated. The inventory of the Collatiehuis in Gouda, dating to the middle of the fifteenth century, mentions a metal firepot or brazier: it seems collationes in the winter months did not need to be heard in the abysmal cold. The Gregoriushuis in Zwolle at least had a fireplace in their collationum to make the meetings more comfortable. The same set of inventories from Gouda also lists a number of cushions or pillows to sit on, which might have been used during the meetings. ${ }^{30}$ Between 1447 and 1450-the period in which Hendrik Herp was rector-additional seating cushions were purchased; as the community of Brothers of the Common Life was rather small, these were likely to be handed out to visitors. ${ }^{31}$

None of the inventories of other houses have survived-at least, not any that concern the furniture or any household items - so it is unclear whether this was standard practice or a peculiarity of the Collatiehuis. Quite possibly other communities either gathered when necessary the available chairs, benches, or cushions to provide seating for their visitors, or perhaps they owned a number of seats. Alternatively, visitors might have brought their own seats: some laypeople owned special, portable chairs known as 'small sermon chairs' (Dutch: preekstoeltjes), designed to bring to church and listen to the sermon in relative comfort. ${ }^{32}$ Although the collatio was no preaching act - a distinction emphatically maintained by the Brothers in their consuetudinesthe two practices are not dissimilar: both are instances of communicating knowledge between religious professionals and an audience of participating laypeople. A portable chair could easily find purpose in both situations: if seating was not already provided by the Brothers, a chair designed to comfortably attend the sermon would work just as well to listen to the collatio.

27 Thom Mertens, Preken met de pen en lezen met de pen. Moderne Devotie en geestelijke literatuur (Deventer: Geert Groote Genootschap, 1989).

28 Hyma, The Christian Renaissance, 448: "[...] motivis et compunctivis verbis corda et voluntates audiencium tangere."

29 Schoengen, Narratio, 247: "Quia vero privata et familiaris allocutio unumquemque plus movet, bonum est, nunc unum, nunc alium in private alloqui, et secundum statum et exigentiam cujusque ad meliora provocare." Compare the Dutch translation in Van Beek, Leken trekken tot Gods woord, 71.

30 Gouda, SAMH, 0091.16 (Lijsten van huisraad en boeken, met het Collatiehuis van de Heilige-Geestmeesters ontvangen, en een opsomming van huisrenten, toebehorende aan het Collatiehuis, ca. 1438-1447/1456. 14381456). The suggestion that these were used during the collatio is from Dlabačová, Literatuur en observantie, 34.

31 Dlabačová, Literatuur en observantie, 36.

32 See Berend Dubbe, "Het huisraad in het Oostnederlandse burgerwoonhuis in de late middeleeuwen," in Thuis in de late middeleeuwen. Het Nederlands burgerinterieur 1400-1535: tentoonstelling in het Provinciaal Overijssels Museum van 5 oktober tot 31 december 1980, ed. Jacobus W.M. de Jong (Zwolle: Waanders, 1980), $29,37$. 
When the collatio moved to the individual cells of the Brothers, the participants might remain standing-after all, the consuetudines demand that the individual conversations go on no longer than 30 minutes or so. ${ }^{33}$ However, since these talks were already more informal than the reading of the collation, it would not be surprising if one or both parties sat on the bed: a very close and confidential arrangement indeed. The collatio was in its entirety meant to be aimed at the heart and move the soul, more humble and personal than preaching a sermon. With this goal in mind, the individual conversations in the rooms of the Brothers might have been the most effective; space, place, and mode of communication working in unison to draw visiting laypeople into the devotional community of the Brothers of the Common Life.

\section{THE COLLATIEHUIS IN THE CITY}

The Collatiehuis, then, was itself composed of multiple lieux de savoir in which laypeople and religious professionals were engaged with each other, and where the communication and transmission of devotional knowledge took different forms depending on the setting. Yet this is but one level on which the Collatiehuis constituted a lieu de savoir: looking inwards to consider the direct surroundings. On a higher level the Collatiehuis had direct surroundings of its own as it was located within the city of Gouda. The collatio opened up the community to the outside world and offered laypeople yet another option, among several, for devotional activity. As mentioned above, the consuetudines stipulate that the Brothers have to wait until the vespers are finished before they may start the collatio: an attempt to no further complicate the competition for the religiously interested layperson's time and attention. The Collatiehuis was but one node within an urban network of other lieux de savoir, and should be considered in relation to its surroundings and how it connected to other religious communities, and to other devotional activities open to laypeople. In particular, it is important to look at preaching activity within the city as a form of closely connected lieux de savoir, as the collatio was to take place after the sermon had finished. Thus, there is already a temporal link between the two lieux de savoir, not to mention other connections between preaching and the collatio; indeed, in the past the collatio has often been characterized as a form of Modern Devout preaching. ${ }^{34}$ Preaching and the collatio shared a common goal: the communication of religious knowledge to laypeople. Those who were interested in sermons would also be the most likely to attend a collatio or other devotional activity.

The most obvious location for preaching in Gouda was the parochial church: the monumental Sint-Janskerk, which had served the parish since 1280. A line can be drawn between the SintJan and the Collatiehuis, both spatial (the Collatiehuis was located right behind the parochial church) and institutional: well within the parish borders, the Brothers of the Common Life had to be in contact with the pastor of the Sint-Jan. Agreements between the parties were put down in 1448 , and again in $1462 .{ }^{35}$ As it was the parish church, the Sint-Jan must have been the site of frequent preaching, though no direct evidence survives of the regular Sunday sermons. Certainly the church provided adequate space: it had been rebuilt as a three-aisled hall church in 1413 , with two more aisles added around $1443 .{ }^{36}$

The Dominicans did not have a proper monastery in Gouda, but the city was within the territory (Dutch: termijngebied) of Utrecht. As such, they did possess a local house (Dutch: termijnhuis or terminarishuis) to aid their preaching activity at least before 1407. This house was located very close to the Collatiehuis: when around 1470 the latter was extended to the south, it incorporated the house of the Dominicans, who moved to a new building across the Spieringstraat. ${ }^{37}$ Visiting Dominicans also preached in Sint-Jan's church on occasion, and assisted in providing pastoral

33 Hyma, The Christian Renaissance, 448: "[...] ad longius ultra dimidiam horam [...]."

34 For instance Gerrit C. Zieleman, De preek bij de moderne devoten (Deventer: Geert Groote Genootschap, 1984).

35 Weiler, Volgens de norm van de vroege kerk, 140-41.

36 Henny van Dolder - de Wit, De Sint-Janskerk in Gouda. Mensen en monumenten in een oude stadskerk, 2nd ed. (Delft: Eburon, 2013), 15-16.

37 Goudriaan, "De verdwenen kloosters," 193. Compare Taal, De Goudse kloosters in de middeleeuwen, 9-10, 60-63; Weiler, Volgens de norm van de vroege kerk, 138-42; Weiler, Monasticon, 212 
care. ${ }^{38}$ At some point, the Carmelite order and the Augustinians from Dordrecht had similar arrangements, though it is unknown when these were established - possibly all three were present in Gouda before $1471 .{ }^{39}$ In 1476 a double monastery (male and female) of Bridgettines was founded as well. It is quite possible that the priests of the monastery preached publicly and in the vernacular: such was after all stipulated in the Brigettine Regula Salvatoris. ${ }^{40}$ However, no traces of preaching in the convent have survived.

Still, Sint-Jan's church was not the only place in Gouda where laypeople could enjoy a good sermon or other religious exercise. From the start of the fifteenth century, the city saw a sudden increase in the number of religious institutions within its borders, among them the Cellites or Alexians (a charitative religious order, who obtained a house near Sint-Jan's church in 1395) and the Franciscans, who settled near the city castle around 1418/1419.41 The latter certainly used their own church to preach to the general population of the city. The parochial church was well aware this might divert listeners from Sint-Jan's church, thereby costing the church money in lost gifts. To prevent this, the friars were forbidden from preaching at those times when a sermon was being delivered in the parochial church; on feast days they could only preach between 12:00 and 14:00; and during Lent they had to remind the listeners that they were required to confess to their own pastor at least once a year-an obligation since Lateran IV, but one that frequently needed to be repeated. ${ }^{42}$ In 1479 Sint-Jan's church and the Franciscans entered into an agreement (the text of which has been lost) on providing sermons in the parochial church. Franciscan sermons would at least be preached on Good Friday and with Easter, and possibly on other occasions as well. ${ }^{43}$

The Gouda city council also maintained good relations with the Friars Minor within the city, though the council does not seem to have paid the friars directly for their preaching activity. Instead, the convent regularly received gifts of wine on special occasions, such as Christmas or St. Francis' day. At times the council would also dine with the Franciscans and pay for the wine and the meal on St. Francis' day. In 1447 the council even decided to give part of that year's financial surplus to the convent. ${ }^{44}$ The Franciscans are the most ubiquitous religious order appearing in the financial accounts, but certainly not the only one: from time to time the Cellites, Carmelites, and Dominicans received gifts of wine as well. Sermons are never mentioned in the financial administration, but the frequent gifts suggest close ties between Gouda and its religious institutions.

With this flourishing of religious life in the fifteenth century, the citizens of Gouda thus had multiple locations in which they could engage in devotional activities - even excluding the private devotional exercises which might call upon the individual believer to withdraw themselves in a secluded space. Importantly, all of these locations were relatively close to each other as Gouda was not exceedingly large: around the year 1500 the city had a population of some 10,000 people, of which 500 were part of a religious community. ${ }^{45}$ In particular the Collatiehuis, the local house of the Dominicans, and the parochial church were very near each other. The collationes were to take place after the vespers in the church had been completed; laypeople eager to participate in additional religious activities would at least not have to go far.

Moreover, the Collatiehuis itself maintained relations with both the city council and other religious communities. They were responsible for celebrating a weekly Mass in the hospice of

38 Harry Pegel, "Prediking voor leken in de stad Utrecht, 1500-1580," in Utrechters entre-deux. Stad en Sticht in de eeuw van de Reformatie, 1520-1620, ed. Hendrik ten Boom et al., Verzameling bijdragen van de Vereniging voor Nederlandse Kerkgeschiedenis 4 (Delft: Eburon, 1992), 100.

39 Taal, De Goudse kloosters in de middeleeuwen, 9-11.

40 See Roger Andersson, "Sermon Manuscripts of Different Kinds," Medieval Sermon Studies 55 (2011): 32-33.

41 On the Friars Minor in Gouda, see Mirjam Schaap, "Over "quaclappers" en ander schadelijk volk. De laatmiddeleeuwse Noord-Nederlandse minderbroederkloosters bezien vanuit de interne machtsstrijd binnen de orde," in Monastiek observantisme en Moderne Devotie in de Noordelijke Nederlanden, ed. Hildo van Engen and Gerrit Verhoeven, Middeleeuwse Studies en Bronnen (Hilversum: Verloren, 2008), 17-41; Koen Goudriaan, "Gouda in de middeleeuwen," in Gouda, ed. Wim Denslagen, De Nederlandse monumenten van geschiedenis en kunst (Zwolle: Waanders, 2001), 13-27; and Goudriaan, "De verdwenen kloosters."

42 Damianus van Heel, De Minderbroeders te Gouda. Deel 1: 1418-1572 (Gouda: [s.n.], 1974), 11-12.

43 Van Heel, De Minderbroeders te Gouda, 34-38.

44 SAMH, 0001 Archief van de stad Gouda, inv. nr. 1130 (stadsrekening 1447), f.25r.

45 Goudriaan, "De verdwenen kloosters," 172. Also see Goudriaan, "Gouda in de middeleeuwen."
DOI: $10.16995 /$ lefou.93 
St. Catharina, as well as the daily Mass at the altar of the Holy Spirit in the Sint-Jan and in the chapel of the castle. ${ }^{46}$ Interaction with the lay population was not limited to the collatio: around 1447-1450, local dignitaries Gerardus Nycolai and his wife Aeff offered the Brothers a gilded silver chalice for their chapel. In return, they were to celebrate 25 Masses yearly in their memory. ${ }^{47}$ It is possible these ceremonies were semi-public, in that close relatives of Gerardus and Aeff were allowed to attend, though there is no mention of them. In any case, it is clear the Collatiehuis was not a solitary lieu de savoir but was intimately connected with the city on all levels.

\section{THE TEXTUAL COLLATION AS A PLACE OF KNOWLEDGE}

In the introduction to Qu'est-ce qu'un lieu de savoir?, Christian Jacob muses on the spaces in which his book has been composed, and the space in which the reader would receive his words, and in what form. This is setting up the importance of spatiality: the spatial dimension has a profound influence on the transmission of knowledge, impacting both the generation of knowledge and its communication. With regard to the reader and their reception of the text, Jacob touches upon a different interpretation of lieux de savoir: the creation of the text is in itself a place of knowledge, as the situation in which it is written influences the text. The digital and the printed text bring with them different connotations and result from (or even necessitate) different physical surroundings. After all, reading from a computer screen in an academic library is not the same as having a physical copy of the text printed for personal use: "Un livre imprimé est lui aussi un lieu de savoir."48

The concept of books as lieux de savoir can be taken further in the context of the collatio. Texts were essential to the practice: the collatio was primarily framed as the reading of a devout text in the vernacular, followed by spiritual conversation. This important link between text and practice is noticeable in the terminology as well, as the Latin collatio or (Middle) Dutch collatie/collacie can refer to both sources. ${ }^{49}$ To make a distinction, this article uses 'collatio' to refer to the practice, whereas 'collation' refers to the written text to be read. However, not every text was a suitable basis for a spiritual conversation. The Brothers of the Common Life made use of books of collations (Latin: collationale; Dutch: collatieboek), which contained multiple texts they could read to the participating laypeople, to aid them in their collationes. In the framework of Jacob, the books of collations should be considered lieux de savoir in that they not only collect and contain knowledge, but also engage with it and provide an opportunity to communicate it. This enabled the books of collations to function within the context of the collatio, and as such they should be considered in greater detail.

In the first place, the books of collations are collections of knowledge in that they contain multiple texts which explain religious doctrine or provide material for increased personal devotion. This is especially apparent when looking at some of the individual collations, for instance those in the First Book of Collations by Dirc van Herxen (1381-1457). ${ }^{50}$ According to Jacobus de Voecht, Brother of the Common Life in Zwolle and chronicler of the house there, Van Herxen had written two large books of collations on various topics in Latin, which he also translated to the vernacular to be used during the public collationes open to schoolboys and interested laypeople. ${ }^{51}$ The First Book of Collations survives in two manuscripts: Leiden, UB BPL 2231 contains only the first part, which deals with the vices, whereas Utrecht, UB 3 L 6 contains both parts, on the vices and the virtues. The latter manuscript also contains a 'reading key' or timetable, making suggestions for which collation to read on a specific day. ${ }^{52}$ The Second Book

46 Weiler, Volgens de norm van de vroege kerk, 148.

47 Taal, De Goudse kloosters in de middeleeuwen, 59.

48 See the introduction, here paragraph 6, of Jacob, Qu'est-ce qu'un lieu de savoir?

49 On the etymology of the term, see Van Beek, Leken trekken tot Gods woord, 61-65.

50 On Dirc van Herxen and the First Book of Collations, see in particular Van Beek, Leken trekken tot Gods woord. Also see 175-187 for examples of other books of collations.

51 Schoengen, Narratio, 56.

52 Alphonsus M.J. van Buuren, " "Wat materien gheliken op sonnendage ende hoechtijde te lesen." Het Middelnederlandse collatieboek van Dirc van Herxen," in Boeken voor de eeuwigheid. Middelnederlands geestelijk proza, ed. Thom Mertens e.a. (Amsterdam: Prometheus, 1993), 252-59. 
of Collations has not yet been discovered; however, it is known that the book was composed of collations on the saints. ${ }^{53}$

The collations of Van Herxen vary in structure: some are largely translations of one source in particular, while others comprise a multitude of sources. For instance, one of the collations on the Last Judgement can be directly traced to two main sources, which were translated by Van Herxen: the seventh chapter of the first book of the Henry Suso's Horologium sapientiae, and Homily 10 of Gregory the Great. ${ }^{54}$ For other collations, Van Herxen drew on a multitude of auctoritates-Augustine, Bernard, Chrysostom, and so on-to construct a collation from quotations and excerpts, often illustrated with exempla from such collections as the Legenda aurea or the Vitas Patrum. To give one example, the collation on marriage makes reference to the New Testament, letters of Jerome, Gregory, and even Geert Grote's De matrimonio. ${ }^{55}$ Van Herxen, or authors of a collation in general, thus composed them from a collection of other sources, adding their own interpretation to the text through their added explanation and the way in which quotations and references were presented. The collation is then the form in which religious knowledge was contained, the result of the strategic use of other texts.

Most importantly, the sources on which the collations draw-and therefore the information they contain-are the same sources the Brothers of the Common Life themselves read to shape their own spirituality. ${ }^{56}$ The collations are part of the textual space in which the Brothers found themselves: a reflection of the texts used for personal meditation, now brought into a new context. The (books of) collations are lieux de savoir, which draw on the spirituality of the Modern Devotion, and collect and contain religious knowledge to be communicated to a lay audience. In turn, laypeople influenced the collatio as well: the circulation of knowledge went both directions. In composing their collations, the Brothers took the lay perspective into account and shaped their texts to be relatable and relevant to their audience. For instance, the aforementioned collation on marriage by Dirc van Herxen was added specifically for laypeople. ${ }^{57}$ The lay influence on the collation also shines through in how marriage is discussed: not as a religious metaphor, but as a worldly issue. While earthly marriage (including sexual relations) is not recommended, it is not judged too harshly. For married people, a devotional life was still very much possible.

Moreover, the books of collations facilitate the communication of the religious knowledge contained within. The collations are to be read during the collatio to the participating laypeople: they are the prime example of the "simple texts that can inspire them to improve their lives". 58 The reading of the collation is an important part of the collatio, as it is the primary manner in which religious knowledge is communicated between religious professionals (the Brothers of the Common Life) and laypeople. With the text, the reader provides his listeners with access to the authoritative figures referred to in the collation, thus both communicating the words of the auctoritas in question and encouraging the recognition of auctoritates. This latter element should be stressed: because the sources for the collation are clearly labelled (often by introducing a passage with, for instance, 'Augustine says...' or 'in a sermon by Gregory, we read...'), frequent visitors of the collatio would soon learn to identify which texts are important if they did not already. This recognition would allow laypeople to seek out other texts, which they could read on their own - a close imitation of the Brothers' own spirituality.

53 See Van Beek, Leken trekken tot Gods woord, 93-95.

54 Compare Utrecht, UB 3 L 6 f. 21v-22r and Henricus Suso, Heinrich Seuses Horologium sapientiae. Erste kritische Ausgabe unter Benützung der Vorarbeiten von Dominikus Planzer OP, ed. Pius Künzle, Spicilegium Friburgense 23 (Freiburg/Schweiz: Universitätsverlag, 1977), 434-36, and Utrecht, UB 3 L 6 f. 22 r-23r and Gregory the Great, Forty Gospel Homilies, trans. David Hurst, Cistercian Studies Series 123 (Kalamazoo, MI: Cistercian Publications Inc, 1990), 72-76.

55 On the references and quotations in this collation, see Lydeke van Beek, "Tussen de doornen pluk ik de rozen. Devote opvattingen over huwelijk en kuisheid in het Eerste Collatieboek van Dirc van Herxen (1381-1457)," Ons Geestelijk Erf 80 (2009): 291-95.

56 On the close relation between religious texts and reading, and the Modern Devout spirituality, see Thomas Kock, "Lektüre und Meditation der Laienbrüder in der Devotio moderna," Ons Geestelijk Erf 76 (2002): 15-63;

Nikolaus Staubach, "Pragmatische Schriftlichkeit im Bereich der Devotio moderna," Frühmittelalterliche Studien 25 (1991): 418-61.

57 Van Beek, Leken trekken tot Gods woord, 146-51.

58 As is prescribed in the consuetudines or customs of Zwolle: Schoengen, Narratio, 247: "[...] de materia plana, que ad emendationem vite eos poterit provocare." 
Moreover, the books of collations show an engagement with the religious knowledge they contain. Authoritative texts are not just scoured for useful quotes to be presented without interpretation. Instead, the collations carefully frame their source materials: both within the collation (references are attributed to their source; multiple quotations on the same issue are presented alongside each other) and in the book of collations as a whole (a single book can contain a multitude of collations on a wide range of topics). The collations employ a myriad of authoritative texts to express the desired devotion. Just as the Collatiehuis was more than the sum of its constituting lieux de savoir, so are the collations more than the collection of their sources. The frequent referral to other texts might give the impression of an unoriginal text-a simple collection of quotations-yet this is the core of the Modern Devout spirituality: the intensive use of authoritative texts to shape one's own devotion. The collations reflect the manner in which the Brothers of the Common Life navigated their shared textual space. The lay audience was thus encouraged to be actively participating in the communication of knowledge, incorporating the example set by the Brothers.

Thus, the books of collations-and by extension the collatio-formed a lieu de savoir: a node in a network of communication of knowledge. Strands of religious knowledge came together in the individual collations, which in turn were contained in the books of collations and communicated in the collatio. The concept of a lieu de savoir can thus be linked directly to the physical object, which is still accessible to this day-indeed, which is the only surviving element of a dynamic, interactive, and collective practice. The participants of the collatio have long since passed away and are often no longer identifiable; their spoken words faded away soon after they spoke them; yet the texts which inspired their conversations remain and give access to the entire textual space in which the Brothers of the Common Life themselves navigated, and in which they invited laypeople to join them.

\section{CONCLUSION}

As this article has shown, the concept of lieux de savoir as theorized by Jacob provides an intriguing framework from which to examine the interactions between laypeople and religious professionals and the transmission of knowledge in the late medieval city. The case of the Collatiehuis in Gouda shows how places of knowledge were interconnected and multifaceted, with a single place being composed of several layers of lieux de savoir. The physical building is but one aspect of 'places' where religious knowledge was shaped and communicated, as it housed several places where laypeople could engage the Brothers of the Common Life in devotional matters. Different rooms within the building provided different settings for new modes of the dissemination of knowledge. The public collatio-the reading of a text inviting the participants to enter into the Modern Devout spirituality-took place in the chapel or perhaps a common room. If a visitor wished to converse with one of the Brothers in private, they would be drawn in further: the cells in the attic provided privacy, and a more intimate setting in which lay and religious engaged in a spiritual discussion.

On the level of the entirety of Gouda, the Collatiehuis constituted but one of several lieux de savoir where laypeople could find religious knowledge. The close proximity of Sint-Jan's church made it easy for eager laypeople to follow up listening to a sermon with participating in the collatio, thus exchanging one lieu de savoir for another. The Collatiehuis maintained relations with several other religious institutions, some of which-like the Holy Ghost masters-also had an interest in running the Collatiehuis and maintaining its function. The Collatiehuis was not an isolated place for devotional activity but was connected to the city at large on more levels than merely the geographical.

At its core, the collationes in the Collatiehuis constituted regular (weekly) lieux de savoir in which laypeople could participate in the social transmission of religious knowledge. The books of collations were part of the dynamic transformation of knowledge, in that the collations directly engaged with authoritative texts and the Modern Devout spirituality. Making use of the same texts the Brothers of the Common Life read for their own spirituality, the collations could draw in laypeople. During the collatio, the collations played an important role in communicating the Modern Devotion to an engaged audience and allowing them to shape their personal devotion along the same lines. The transmission of religious knowledge is closely linked to the textual collations and the dynamics of the collatio, yet the spatiality of the Collatiehuis put an important mark on the proceedings.
DOI: $10.16995 /$ lefou.93 
AUTHOR AFFILIATION

Pieter H. Boonstra (D) orcid.org/0000-0002-1014-1574

University of Groningen, NL

\section{REFERENCES}

Andersson, Roger. "Sermon Manuscripts of Different Kinds." Medieval Sermon Studies 55 (2011): 31-44. DOI: https://doi.org/10.1179/136606911X13100359884834

Beek, Lydeke van. Leken trekken tot Gods woord. Dirc van Herxen (1381-1457) en zijn Eerste Collatieboek. Hilversum: Verloren, 2009.

Beek, Lydeke van. "Tussen de doornen pluk ik de rozen. Devote opvattingen over huwelijk en kuisheid in het Eerste Collatieboek van Dirc van Herxen (1381-1457)." Ons Geestelijk Erf 80 (2009): 281-312. DOI: https://doi.org/10.2143/OGE.80.4.2047111

Boonstra, Pieter H. "Causa Spiritualis Instructionis. The Modern Devout Collatio as a Community of Learning". Ons Geestelijk Erf 88 (2017): 35-57. DOI: https://doi.org/10.2143/OGE.88.1.3248513

Buuren, Adolphus M.J. van. "'Wat materien gheliken op sonnendage ende hoechtijde te lesen." Het Middelnederlandse collatieboek van Dirc van Herxen." In Boeken voor de eeuwigheid. Middelnederlands geestelijk proza, edited by Thom Mertens e.a., 245-63. Amsterdam: Prometheus, 1993.

Carlier, Johannes H. "Het Fraterhuis of Collatiehuis op de Jeruzalemstraat." Bijdragen Oudheidkundige Kring Die Goude (Gouda) 5 (1947): 50-77.

Dlabačová, Anna. Literatuur en observantie. De Spieghel der volcomenheit van Hendrik Herp en de dynamiek van laatmiddeleeuwse tekstverspreiding. Middeleeuwse Studies en Bronnen, CXLIX. Hilversum: Verloren, 2014.

Dolder - de Wit, Henny van. De Sint-Janskerk in Gouda. Mensen en monumenten in een oude stadskerk. 2nd ed. Delft: Eburon, 2013.

Dubbe, Berend. "Het huisraad in het Oostnederlandse burgerwoonhuis in de late middeleeuwen." In Thuis in de late middeleeuwen. Het Nederlands burgerinterieur 1400-1535: tentoonstelling in het Provinciaal Overijssels Museum van 5 oktober tot 31 december 1980, edited by Jacobus W.M. de Jong, 21-80. Zwolle: Waanders, 1980.

Goudriaan, Koen. "De verdwenen kloosters." In Gouda, edited by Wim Denslagen, 171-211. De Nederlandse monumenten van geschiedenis en kunst. Zwolle: Waanders, 2001.

Goudriaan, Koen. "Gouda in de middeleeuwen." In Gouda, edited by Wim Denslagen, 13-27. De Nederlandse monumenten van geschiedenis en kunst. Zwolle: Waanders, 2001.

Goudriaan, Koen., Martha Hulshof, and Ad L. Tervoort. "Rijk liefdewerk in een arme stad." In Duizend jaar Gouda. Een stadsgeschiedenis, by Paul H.A.M. Abels, 135-73. Bijdragen/Historische Vereniging Die Goude 30. Hilversum: Verloren, 2002.

Gregory the Great. Forty Gospel Homilies. Translated by David Hurst. Cistercian Studies Series 123. Kalamazoo, MI: Cistercian Publications Inc, 1990.

Heel, Damianus van. De Minderbroeders te Gouda. Deel 1: 1418-1572. Gouda: [s.n.], 1974.

Henricus Suso. Heinrich Seuses Horologium sapientiae. Erste kritische Ausgabe unter Benützung der Vorarbeiten von Dominikus Planzer OP. Edited by Pius Künzle. Spicilegium Friburgense 23. Freiburg/Schweiz: Universitätsverlag, 1977.

Hyma, Albert. The Christian Renaissance. A History of the 'Devotio Moderna'. Grand Rapids, MI: The Reformed Press, 1924.

Jacob, Christian. Qu'est-ce qu'un lieu de savoir? Encyclopédie numérique 2. Marseille: OpenEdition Press, 2014. http://books.openedition.org/oep/423.

Klausmann, Theo. Consuetudo consuetudines vincitur. Die Hausordnungen der Brüder vom gemeinsamen Leben im Bildungs- und Sozialisationsprogramm der Devotio moderna. Tradition - Reform Innovation. Studien zur Modernität des Mittelalters 4. Frankfurt am Main: Peter Lang, 2003.

Klein, Jan Willem. "De Goudse boekcultuur tot 1600: Het begin en de Collatiebroeders."

Tidinge van de Goude 38 (2020): 88-99.

Kock, Thomas. "Lektüre und Meditation der Laienbrüder in der Devotio moderna." Ons Geestelijk Erf 76 (2002): 15-63. DOI: https://doi.org/10.2143/OGE.76.1.565498

Kruitwagen, Bonaventura. "Het "Speculum Exemplorum"." Bijdragen voor de Geschiedenis van het Bisdom van Haarlem 29 (1905): 329-453.

Lem, Constant A.M. "De consuetudines van het Collatiehuis in Gouda." Ons Geestelijk Erf 65 (1991): 125-43. DOI: https://doi.org/10.2143/OGE.65.2.2017667

Luijk, Madelon van. Bruiden van Christus. De tweede religieuze vrouwenbeweging in Leiden en Zwolle, 1380-1580. Zutphen: Walburg Pers, 2004.

Mertens, Thtom. Preken met de pen en lezen met de pen. Moderne Devotie en geestelijke literatuur. Deventer: Geert Groote Genootschap, 1989. 
Pegel, Harry. "Prediking voor leken in de stad Utrecht, 1500-1580." In Utrechters entre-deux. Stad en Sticht in de eeuw van de Reformatie, 1520-1620, edited by Hendrik ten Boom, Liesbeth Geudeke, Huib L.Ph. Leeuwenberg, and Paul H.A.M. Abels, 112-46. Verzameling bijdragen van de Vereniging voor Nederlandse Kerkgeschiedenis 4. Delft: Eburon, 1992.

Schaap, Miriam. "Over "quaclappers" en ander schadelijk volk. De laat-middeleeuwse Noord-Nederlandse minderbroederkloosters bezien vanuit de interne machtsstrijd binnen de orde." In Monastiek observantisme en Moderne Devotie in de Noordelijke Nederlanden, edited by Hildo van Engen and Gerrit Verhoeven, 17-41. Middeleeuwse Studies en Bronnen. Hilversum: Verloren, 2008.

Schoengen, Michael, ed. Jacobus Traiecti alias De Voecht: Narratio de inchoatiane domus clericorum in Zwollis. Met akten en bescheiden betreffende dit fraterhuis. Amsterdam: Johannes Müller, 1908.

Staubach, Nikolaus. "Die Devotio moderna als Textgemeinschaft." In Schnittpunkte. DeutschNiederländische Literaturbeziehungen im späten Mittelalter, edited by Angelika Lehmann-Benz, Ulrike Zellmann, and Urban Küsters, 19-40. Münster: Waxmann, 2003.

Staubach, Nikolaus. "Pragmatische Schriftlichkeit im Bereich der Devotio moderna." Frühmittelalterliche Studien 25 (1991): 418-61. DOI: https://doi.org/10.1515/9783110242232.418

Stock, Brian. The Implications of Literacy. Written Language and Models of Interpretation in the Eleventh and Twelfth Centuries. Princeton: Princeton University Press, 1983.

Taal, Johannes. De Goudse kloosters in de middeleeuwen. Hilversum: Paul Brand, 1960.

Van Engen, John. "Multiple Options: The World of the Fifteenth-Century Church." Church History 77 (2008): 257-84. DOI: https://doi.org/10.1017/S0009640708000541

Van Engen, John. Sisters and Brothers of the Common Life. The Devotio Moderna and the World of the Later Middle Ages. Philadelphia: University of Pennsylvania Press, 2008. DOI: https://doi. org/10.9783/9780812290059

Weiler, Anton G. Monasticon fratrum vitae communis, TI. III: Niederlande. Brussel: Archives et bibliothèques de Belgique, 2004.

Weiler, Anton G. "The Dutch Brethren of the Common Life, Critical Theology, Northern Humanism and Reformation." In Northern Humanism in European Context, 1469-1625. From the 'Adwert Academy' to Ubbo Emmius, edited by Fokke Akkerman, Arjo J. Vanderjagt, and Adrie H. van der Laan, 307-32. Leiden: Brill, 1999. DOI: https://doi.org/10.1163/9789004247482_019

Weiler, Anton G. Volgens de norm van de vroege kerk. De geschiedenis van de huizen van de broeders van het Gemene leven in Nederland. Middeleeuwse Studies, XIII. Nijmegen: Centrum voor Middeleeuwse Studies Katholieke Universiteit Nijmegen, 1997.

Zieleman, Gerrit C. De preek bij de moderne devoten. Deventer: Geert Groote Genootschap, 1984.
TO CITE THIS ARTICLE:

Boonstra, Pieter H. "In Ecclesia Nostra: The Collatiehuis in Gouda and Its Lieux de Savoir." Le foucaldien 7, no. 1 (2021): 5, 1-13. DOI: https:// doi.org/10.16995/lefou.93

Submitted: 06 October 2020 Accepted: 06 February 2021 Published: 17 May 2021

\section{COPYRIGHT:}

(c) 2021 The Author(s). This is an open-access article distributed under the terms of the Creative Commons Attribution 4.0 International License (CC BY 4.0), which permits unrestricted use, distribution, and reproduction in any medium, provided the original author and source are credited. See http://creativecommons.org/ licenses/by/4.0/.

Le foucaldien is a peerreviewed open access journal published by Open Library of Humanities. 